L. Boldyreiva,

Doctor of Economic Sciences, Associate Professor, Associate Professor

of the Department of management and logistics,

National University "Yuri Kondratyuk Poltava Polytechnic"

ORCID ID 0000-0002-9147-5524

V. Gryshko,

$P h D$ in Economics, Associate Professor of the Department of management and logistics, National University "Yuri Kondratyuk Poltava Polytechnic"

ORCID ID: 0000-0001-6987-3879

\title{
EUROPEAN EXPERIENCE \\ OF SMART-TECHNOLOGY \\ IMPLEMENTATION IN LOGISTIC PROCESS MANAGEMENT
}

\author{
1. М. Болдирева, \\ А. е. Н., Аоцент, доцент кафедри менеджменту і логістики, \\ Національний університет "Полтавська політехніка імені Юрія Кондратюка" \\ В. В. Гришко, \\ к. е. н., доцент кафедри менеджменту і догістики, \\ Національний університет "Полтавська політехніка імені Юрія Кондратюка"
}

\author{
ЄВРОПЕЙСЬКИЙ АОСВІА ВПРОВААЖЕННЯ СМАРТ-ТЕХНОЛОГІЙ В УПРАВАІННІ \\ АОГІСТИЧНИМИ ПРОЦЕСАМИ
}

\begin{abstract}
The economic development due to the use of start-up technologies in the management of logistics processes is investigated. The experience of leading European companies is analyzed, which is accompanied by continuous introduction of the latest smart technologies in the system of logistics process management. The basic principles of logistics of smart technologies in the system of management of logistic processes are formulated such as: system, accuracy, reliability, efficiency, security, optimization, competence, mobility, productivity, economy and efficiency. Features of smart technologies are distinguished: Smart Logistics Grid (planning, optimization, provisioning, coordination and control), Smart Transportation (creation, provisioning and control), Smart Government (provisioning and optimization), Smart City (provisioning, optimization and management decision making), Smart London (management optimization and decision making), Smart ecosystem (integrated approach), Innovate18 (security), Heathrow pod (security), Blockchain platform (security, optimization), Smart Contracts (optimization, control), Smart Sensor (control) in the logistics management system eyes. It has been proven that automated and digitized logistic processes minimize the use of human labor and paper documents, and as a result of the implementation, in particular of artificial intelligence platforms, can: first, provide comprehensive analysis and control of the supply chain; secondly, to improve the following functional areas of logistics: information logistics, supply logistics, transport logistics, distribution logistics, marketing logistics, warehouse logistics and inventory management, and more. The following main components of the cumulative economic effect of applying a logistic approach are proposed: effective coordination; integration of logistics resources; quality and efficiency control in various areas; establishing partnerships with suppliers; reducing
\end{abstract}




\section{ЕКОНОМІЧНА НАУКА}

order processing time, downtime, production cycle and logistics costs; improving product quality; optimization of integrated management structures; improving the reliability of workflow and quality of the logistics product; updating real-time data across all links in the logistics chain; reduction of logistical risks.

Досліджено економічний розвиток внаслідок застосування Старт-технологій в уПравАінні Аогістичними Процесами. Проаналізовано досвід передових європейських компаній, що супроводжується поСтійним впровадженням новітніх смарт-технологій в Системі управління Аогістичними процесами. Сфор-

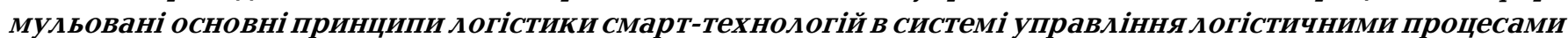
такі: системність, точність, надійність, оперативність, безпечність, оптимізація, компетентність, мобільність, продуктивність, економічність і ефективність. Виокремлено функції смарт-технологій: Sтагt Logistics Grid (Планування, оптимізація, забезпечення, координування і контроль), Smart Transportation (створення, забезпечення і контроль), Smart Government (забезпечення і оптимізація), Smart City (забезпечення, оптимізація і прийняття управлінських рішень), Smart London (оптимізація і прийняття управАінських рішень), Смарт-екосистема (комплексний підхі,), Innovate18 (забезпечення), Неаthrow род (забезпечення), Blockchain-платрорма (забезпечення, оптимізація), Smart Contracts (оптимізація, контроль), Smart Sensor (контроль) у системі управління Аогістичними процесами. Доведено, що автоматизовані та оцифровані логістичні процеси дозволяють мінімізувати використання Аюдської праці та паперових, окументів, а внаслідок впровадження, зокрема платформ штучного інтелекту можна: по-перше, отримати всебічний аналіз і контроль Аанцюга поставок; по-Аруге, досяГти Удосконалення таких функціональних сфер Аогістики: інформаційної Аогістики, Аогістики постачання, транспортної Аогістики, розподільчої Аогістики, маркетинг-Аогістики, СКАадСьӧ̈ Аогістики і управління запаСами тощо. Запропоновано такі основні СкАадові СукуПного економічного ефекту від застосування Аогістичного підходу: ефективне координування; інтегрування логістичних ресурсів; контроль якості та ефективності обслуговування в різних сферах; налагодження партнерських взаємовідносин з постачальниками; скорочення часу обробКИ замовлення, Простою обладнання, виробничого цикАУ Та АогіСтичних витрат; підвищення якості ПроАукції; оптимізація інтегрованих структур управління; підвищення надійності документообігу і якості логістичного продукту; оновлення,даних в реальному часі за всіма Аанками Аогістичного Аанцюга; зменшення логістичних ризиків.

Key words: control, delivery lancing, logistics, logical processes, smart technologies, management, management solutions.

Ключові слова: контроль, ланчюги поставок, логістика, логістичні прочеси, смарт-технологї, управління, управлінські рішення.

\section{FORMULATION OF THE PROBLEM}

Formation of information-network economy in Ukraine is possible only through the use of modern digital technologies. The intellectual-intensive model of Ukraine's development is possible due to the rapid dissemination of knowledge and the emergence of new logistics technologies. The experience of Germany, France and the Netherlands shows that the use of digital smart technologies significantly increases the cost-effectiveness and environmental safety of organizations, in particular, increasing productivity and profitability. At the moment there is a complete technologicalization of enterprises and organizations. In particular, IT technologies open up information to all consumers anywhere in the world.

\section{ANALYSIS OF RECENT RESEARCH} AND PUBLICATIONS

Innovative Smart-technologies in logistics management are actively used worldwide. The effectiveness of their application has been discussed by many researchers. Thus, W. Albrecht [4] in his writings investigated the Smart Logistics Grid.Matthew N.O. Sadiku, Adebowale E. Shadare, Sarhan M. Musa [6] dealt with issues related to Smart Transportation.M. Grigorak developed: "Conceptual Provisions for Developing a National Logistic Strategy in the Geoeconomic Dimension" [5], and in the monograph "Intellectualization of the Logistics Services Market: Concept, Methodology, Competence", the researcher suggested organizational and managerial measures for realizing the logistical potential of Ukraine in the system of global logistic systems. using modern information and communication technologies [3]. However, a number of unresolved issues remained unanswered.

\section{THE AIM OF THE STUDY}

Research of the European experience of introduction of smart technologies in management of logistic processes of organizations.

\section{OUTLINE OF THE MAIN RESEARCH} MATERIAL

Humanity has entered a new stage of civilization, the concept of which is: "values create knowledge, and the economy is a system that operates on the basis of knowledge sharing and mutual evaluation" [1, p. 43].

Due to innovations and trends, the logistics industry is changing dramatically. The modern economy is being transformed by such basic key technologies [2, p. 320; 3; with. 10]:

- global databases on obstacles and risks;

- 3D printing for niche markets;

- sensor technologies;

- Augmented Reality (Smart Augmented Reality Smart Glasses scan barcodes and listings that list locations and delivery points);

- works (warehouse operators);

- drones (Parcelcopter was successfully tested in Germany in May 2016);

- cloud solutions (service through an IT resource in the form of a corresponding model of service in the remote access mode. IT resources work in the technology of a single chain integrated into a single configuration of a virtual computer).

Research shows that economic development due to the use of start-up technologies in the management of logistics processes is associated with the process of transportation and location of warehouses, the use of e-commerce, as well 
Table 1. Smart technologies in the logistic process management system

\begin{tabular}{|c|c|c|}
\hline Names & Functions & Content, the essence \\
\hline 1 & 2 & 3 \\
\hline \multirow{5}{*}{$\begin{array}{l}\text { Smart } \\
\text { Logistics } \\
\text { Grid }\end{array}$} & Planning & $\begin{array}{l}\text { Transportation taking into account situations on roads and vacant sites on } \\
\text { loading and unloading areas }\end{array}$ \\
\hline & Optimization & Flexibility of distribution networks without increasing inventory \\
\hline & Software & Workload Balancing \\
\hline & Coordination & Effective coordination; integration of logistics resources \\
\hline & Control & Quality control \\
\hline \multirow[t]{3}{*}{$\begin{array}{l}\text { Smart } \\
\text { transportation }\end{array}$} & Creation & $\begin{array}{l}\text { Intelligent transport and logistics systems that provide monitoring and schedule } \\
\text { management }\end{array}$ \\
\hline & Software & Intelligent parking and alert service at public transport stops \\
\hline & Control & Paying tolls, responding to emergencies, managing traffic lights \\
\hline \multirow[t]{2}{*}{$\begin{array}{l}\text { Smart } \\
\text { Government }\end{array}$} & Software & $\begin{array}{l}\text { Information technology for providing public services to a wide range of } \\
\text { individuals }\end{array}$ \\
\hline & Optimization & The work of different departments \\
\hline \multirow[t]{8}{*}{ Smart city } & \multirow[t]{5}{*}{ Software } & $\begin{array}{l}\text { The holistic concept of smart integration of information and communication } \\
\text { technologies for monitoring and managing urban infrastructure }\end{array}$ \\
\hline & & Improving people's lives byimproving comfort and safety \\
\hline & & Quality and efficiency of service in various fields \\
\hline & & Operation of non-motorized vehicles \\
\hline & & Installation of a wide network of video surveillance and video analytics \\
\hline & Optimization & Costs and resources \\
\hline & \multirow{2}{*}{$\begin{array}{l}\text { Making } \\
\text { management } \\
\text { decisions }\end{array}$} & A variety of solutions based on the introduction of smart technologies \\
\hline & & Alternative approaches to energy supply and water supply \\
\hline \multirow[t]{3}{*}{ Smart london } & \multirow[t]{2}{*}{ Software } & $\begin{array}{l}\text { Arrangement of intelligent network road transport systems, digital platforms } \\
\text { for making payments and conductinga dministrative affairs }\end{array}$ \\
\hline & & Energy saving technologies and services to enhance urban security \\
\hline & $\begin{array}{l}\text { Making } \\
\text { management } \\
\text { decisions } \\
\end{array}$ & A database for decision making \\
\hline $\begin{array}{l}\text { Smart - } \\
\text { Ecosystems }\end{array}$ & $\begin{array}{l}\text { Complex } \\
\text { approach }\end{array}$ & Solving common problems \\
\hline \multirow[t]{2}{*}{ Innovate18 } & \multirow[t]{2}{*}{ Software } & Underground railway network \\
\hline & & $\begin{array}{l}\text { High-speed Crossrail safe freight and passenger transportation based on } \\
\text { innovative approaches; }\end{array}$ \\
\hline Heathrowpod & Software & $\begin{array}{l}\text { An operational transit system, taking into account the wishes of its employees } \\
\text { and passengers (refusal of regular bus services on the territory of theairport) }\end{array}$ \\
\hline \multirow{9}{*}{$\begin{array}{l}\text { Blockchain- } \\
\text { platform }\end{array}$} & \multirow[t]{2}{*}{ Software } & Real-time measurement of location, temperature, humidity and power supply \\
\hline & & Accessibility and unification of information \\
\hline & \multirow[t]{7}{*}{ Optimization } & Integrated management structures \\
\hline & & Improving the reliability of workflow \\
\hline & & Improving the quality of the logistics product \\
\hline & & Updating real-time data across all links in the logistics chain \\
\hline & & Reduction of order processing time \\
\hline & & Reduction of logistics costs \\
\hline & & Reduction of logistical risks \\
\hline \multirow{2}{*}{$\begin{array}{l}\text { Smart } \\
\text { contracts }\end{array}$} & Optimization & \multirow{2}{*}{$\begin{array}{l}\text { A computer algorithm for generating, controlling, and providing information } \\
\text { about owning something }\end{array}$} \\
\hline & Control & \\
\hline Smart sensor & Control & The use of rfid tags and built-in temperature sensors \\
\hline
\end{tabular}

Source: own design.

as systems for managing the supply chain of consumer value.

Every year in the field of logistics, in particular transport, international forums, conferences and exhibitions take place, presenting the trends of innovative technological developments of the future:

- the European Logistics Information Technology Forum (CIO Forum EU) brought together more than 250 IT professionals and industry experts representing European logistics providers (Amsterdam, The Netherlands);

- SITL Europe Forum for Transport, Logistics and Supply Chains (freight products and services; various types of freight: urban logistics, rail, air, sea, safe cargo, importexport, robotics), France);

- TOC Europe Forum for Port, Shipping and Terminal Technologies, SME Village and a platform for representatives of ports and associations (Rotterdam, The Netherlands);

- The European 3PL \& Supply Chain Summit (European 3PL Logistics \& Supply Chain Summit) is organized on topics such as dynamism, transparency, rapid response and development (Brussels, Belgium);
- LogiMAT exhibits production-sales-transportation intrologistics, in particular innovative technologies, products, systems and solutions for optimizing operations, processes and reducing the company's internal logistics costs (Stuttgart, Germany);

- Leaders in Logistics: Post and Parcel Summit (Post Operators Summit) works in the following areas: digital transformation, innovative solutions, last mile delivery and parcel delivery and delivery strategy (Copenhagen, Denmark);

- exhibition PARCEL + POST EXPO of innovations and technologies that can help during freight transportation (Vienna, Austria);

- Intermodal Europe 2020 Exhibition and Conference is related to container and intermodal logistics, including all types of container transportation and logistics by road, rail and sea (companies representing: Seaco, Maersk Container Industry, Caru Containers, etc.)

- Logistics meets Innovation conference for logistics and networking companies: Amazon, DHL, ECS, Kuehne + Nagel, LKW Walter, Lufthansa Cargo, NileDutch, Panalpina, Pfizer, Novartis and others. (optimization of 
capacity utilization; large data sets for planning and optimization forecasting; cooperation in logistics; the role and impact of artificial intelligence and practical techniques for its use in modern logistics) (Brussels, Belgium);

- BVL 37th International Supply Chain Conference on Supply Chain Conference in Supply Chain Management, a platform for interaction between logistics, transport and services entrepreneurs, manufacturing, scientists, policy makers and journalists (Berlin, Germany) );

- HyperLOG exhibition in the field of transport, freight forwarding and logistics (Warsaw, Poland).

Therefore, the activities of leading European companies are accompanied by the continuous introduction of the latest smart technologies in the logistics management system.In Ukraine known are: Smart Logistics Grid, Smart Transportation, Smart Government, Blockchain, IoT \& smart contracts, Smart City.

The innovative concept of efficient planning and use of logistical resources in the distribution networks of goods movement, taking into account various factors - Smart Logistics Grid, became widespread.This concept is an innovative product of PSI Logistics, a company that develops advanced software of the highest quality. The term "Smart Grid" itself is borrowed from the energy sector and is interpreted as a "smart grid" [4]. In our opinion, the functions of Smart Logistics Grid are: planning, optimization, provisioning, coordination and control.

Smart Transportation (smart transportation as a component of a smart city) improves safety, increases productivity and provides environmental friendliness through the use of information and communication technologies on road transport and other vehicles, in infrastructure [6, p. 6]. In our opinion, Smart Transportation's functions are: creation, provisioning and control.

Smart Government is the use of technology to facilitate and support better planning and management decisions. In our view, the functions of Smart Government are: provision and optimization. Smart City is a state-of-the-art technology in the smart city system. In our opinion, Smart City is: providing, optimizing and making management decisions.

Therefore, smart technologies in the logistics management system have such basic principles of logistics as systemability, accuracy, reliability, efficiency, security, optimization, mobility, competence, productivity, economy and efficiency.

We have generalized the scientific works of both European and domestic researchers [ $4 ; 6-10]$, which highlights the benefits of smart technologies in the management of logistics processes (table. 1).

The blockchain platform is open source, which allows organizations worldwide to implement blockchain technology in their own business processes [8, p. 49; 9].Very common importance has become:

- a way to equip containers with a start-sensor device (use of high-frequency RFID tags and built-in temperature sensors) allows clients of the organization to monitor temperature modes, and in case of their violation receive warning signals;

- connection of vehicles to the Internet allows to manage traffic and to carry out monitoring of transport;

- creation of online platforms for carriers automates the management of electronic records, transport and warehouses, receipt of orders, aggregation of operations of the delivery service and instant calculation of delivery rates;

- introduction of 3D printing in the production of various items: spare parts, architectural models, functional prototypes, mounts for cameras, used props, lighting and cables;

- Blockchain and Smart Contracts technologies allow for sale and delivery contracts without human involvement at all (payment is made using the blockchain system) [8, p. 49; 9];
- introduction of artificial intelligence and Machine Learning as a variant of it allows: first, to increase efficiency of logistic business and to take customer service to a new level; secondly, to improve the systematic management of organizations by establishing and synchronizing internal and external business processes [8, p. 50; 10].

Thus, automated and digitized logistic processes minimize the use of human labor and paperwork, and through the introduction, in particular of artificial intelligence platforms, can: firstly, provide comprehensive analysis and control of the supply chain; secondly, to improve the following functional areas of logistics: information logistics, supply logistics, transport logistics, distribution logistics, marketing logistics, warehouse logistics, inventory management and more.

Electronic technologies are considered as very promising and effective: EDI, RFID, e-mobility; e-business; e-logistics, etc.

For example, agriculture uses such digital technologies as: DroneUA, SmartFarming, MegaDrone, AgroDrone. Among the providers of agrarian software are the following: Cropio, TVIS, Klever Systems. For agricultural control AgriEye, PreAgri, Agroonline, Fieldlook. As digital technologies help increase efficiency and productivity, they create opportunities for successful decisions and minimize risks, so Ukrainian farmers are interested in using integrated software solutions to run their own businesses.

Therefore, the introduction of the latest smart technologies in the logistics management system can achieve an economic effect. The implementation of which involves assessing the cumulative economic effect of applying a logistic approach. The result of the economic effect depends on the efficiency of logistics solutions in production, individual logistics operations associated with the transformation of material flow, evaluation of the functioning of the logistics system and the increase in overall efficiency. The main components of the cumulative economic effect of applying a logistic approach are: effective coordination; integration of logistics resources; quality and efficiency control in various areas; establishing partnerships with suppliers; reducing order processing time, downtime, production cycle and logistics costs; improving product quality; optimization of integrated management structures; improving the reliability of workflow and quality of the logistics product; updating real-time data across all links in the logistics chain; reduction of logistical risks.

\section{CONCLUSIONS}

Thus, the experience of leading European companies involves the continuous introduction of the latest smart technologies in the logistics management system. The basic principles of smart technology logistics in the logistics management system are: system, accuracy, reliability, efficiency, security, optimization, competence, mobility, productivity, efficiency and efficiency.Smart technology features are: Smart Logistics Grid (planning, optimization, provisioning, coordination and control), Smart Transportation (creation, provisioning and control), Smart Government (provisioning and optimization), Smart City (provisioning, optimization and management decision making), Smart London (management optimization and decision-making), Smart ecosystem (integrated approach), Innovate18 (security), Heathrow pod (security), Blockchain platform (security, optimization), Smart Contracts (optimization, control), Smart Sensor ( control) in the logistics management system eyes.Automated and digitized logistic processes minimize the use of human labor and paperwork, and through the introduction, in particular of artificial intelligence platforms, can: first, provide comprehensive analysis and control of the supply chain; secondly, to improve the following functional areas of logistics: information logistics, supply logistics, transport logistics, distribution logistics, marketing logistics, 
warehouse logistics and inventory management, and more. The main components of the cumulative economic effect of applying a logistic approach include: effective coordination; integration of logistics resources; quality and efficiency control in various areas; establishing partnerships with suppliers; reducing order processing time, downtime, production cycle and logistics costs; improving product quality; optimization of integrated management structures; improving the reliability of workflow and quality of the logistics product; updating real-time data across all links in the logistics chain; reduction of logistical risks.

A promising direction for further research will be the systematization of scientific sources on smart technologies in the transport logistics management system.

\section{Мітература:}

1. Сакайя Т. Стоимость, создаваемая знаниями, или История будущого. Новая постиндустриальная волна на Западе. Антология; под ред. В.И. Иноземцева. М.: Academia, $1999.640 \mathrm{c}$.

2. Марченко О.В., Кириченко Н.В. Тенденції розвиткy Smart-технологій в логістиці. Сучасні тренди та перспективи логістики, маркетингу, збутової діяльності плодоовочівництва в епоху цифрових технологій: матеріали Міжнародної науково-практичної конференції, присвяченої 35-річчю Економічного факультету, м. Херсон, 20-21 вересня 2019 р.); за заг. ред. О.В. Аверчева. Херсон: Видавничий дім "Гельветика", 2019. С. 320-322.

3. Григорак М.Ю. Інтелектуалізація ринку логістичних послуг: концепція, методологія, компетентність: монографія. Київ: Сік Груп Україна, 2017.513 с.

4. Альбрехт B. Smart Logistics Grid: Разветвленнаялогистическая система с процесами взаимодействия. Production Manager. 2011. № 1. URL: https://www.psi.de.

5. Григорак М.Ю. Концептуальні положення розроблення національної логістичної стратегії в геоекономічному вимірі. Інтелект XXI. № 4. 2017. С. 58-64.

6. Matthew N.O. Sadiku, Adebowale E. Shadare, Sarhan M. Musa.Smart Transportation: A Primer. IJARCSSE All Rights Reserved. 2017. Vol. 7. Issue 3. 6$7 \mathrm{pp}$.

7. Smart City: Як правильно застосувати світовий досвід в Україні. 2018. URL:https://nv.ua/ukr/biz/ experts/smart-city-yak-pravilno-zastosuvati-svitoviydosvid-v-ukrajini-2506784.html

8. Смирнова Н.В.Перспективи застосування технологій Blockchain, смарт-контрактів та Machine Learning в інноваційному розвитку логістики. Сучасні тренди та перспективи логістики, маркетингу, збутової діяльності плодоовочівництва в епоху цифрових технологій: матеріали Міжнародної науково-практичної конференції, присвяченої35-річчю Економічного факультету, м. Херсон, 20-21 вересня 2019 р.); за заг. ред. О.В. Аверчева. Херсон: Видавничий дім "Гельветика", 2019. С. 48-52.

9. Технологияblockchain в логистике. URL: https:// logist.fm/publications/tehnologiya-blockchain-v-logistike

10. Mitchell-Keller L. End-to-end: Machine Learning Benefits. The Whole Supply Chain. URL: https://multichannelmerchant.com/blog/end-to-endmachinelearning-benefits-the-whole-supply-chain/

\section{References:}

1. Sakajja, T. (1999), "The value created by knowledge, or the history of the future", Novaja postindustrial'naja volna na Zapade. Antologija [A new post-industrial wave in the West. Anthology], Academia, Moscow, Russia.

2. Larchenko, O.V. and Kyrychenko, N.V. (2019), "Trends in the development of Smart technologies in logistics", Suchasni trendy ta perspektyvy lohistyky, marketynhu, zbutovoi diial'nosti plodoovochivnytstva $\mathrm{v}$ epokhu tsyfrovykh tekhnolohij: materialy Mizhnarodnoi naukovo-praktychnoi konferentsii, prysviachenoi 35richchiu Ekonomichnoho fakul'tetu [Modern Trends and Prospects for Logistics, Marketing, Marketing of Fruit and

Vegetable Production in the Digital Age: Proceedings of the International Scientific Conference on the 35th Anniversary of the Faculty of Economics], Kherson, Ukraine, 20-21 September 2019, pp. 320-322.

3. Hryhorak, M.Yu. (2017), Intelektualizatsiia rynku lohistychnykh posluh: kontseptsiia, metodolohiia, kompetentnist' [Intellectualization of the logistics services market: concept, methodology, competence], Sik Hrup Ukraina, Kyiv, Ukraine.

4. Al'breht, V. (2011), "Smart Logistics Grid: An extensive logistic system with interaction processes", Production Manager, vol. 1, available at: https://www.psi.de (Accessed 10 March 2020).

5. Hryhorak, M.Yu. (2017), "Conceptual provisions for developing a national logistics strategy in the geo-economic dimension", Intelekt XXI, vol. 4, pp. 58-64.

6. Sadiku, M. N.O. Shadare, A. E.and Musa, S. M. (2017), "Smart Transportation: A Primer", IJARCSSE All Rights Reserved, Vol. 7, no. 3, pp. 6-7.

7. nv.ua (2018), "Smart City: How to apply the world experience in Ukraine correctly", available at: https:// nv.ua/ukr/biz/experts/smart-city-yak-pravilnozastosuvati-svitoviy-dosvid-v-ukrajini-2506784.html (Accessed 10 March 2020).

8. Smyrnova, N.V. (2019), "Prospects for the use of Blockchain technologies, smart contracts and Machine Learning in innovative logistics development", Suchasni trendy ta perspektyvy lohistyky, marketynhu, zbutovoi diial'nosti plodoovochivnytstva $v$ epokhu tsyfrovykh tekhnolohij: materialy Mizhnarodnoi naukovo-praktychnoi konferentsii, prysviachenoi 35-richchiu Ekonomichnoho fakul'tetu, m. Kherson [Modern Trends and Prospects for Logistics, Marketing, Marketing of Fruit and Vegetable Production in the Digital Age: Proceedings of the International Scientific Conference on the 35 th Anniversary of the Faculty of Economics], Kherson, Ukraine, 20-21 September 2019, pp. 48-52.

9. logist.fm (2017), "Blockchain technology in logistics", available at: https://logist.fm/publications/tehnologiyablockchain-v-logistike (Accessed 10 March 2020).

10. Mitchell-Keller, L. (2017), "End-to-end: Machine Learning Benefits. The Whole Supply Chain", available at: https:/9 multichannelmerchant.com/blog/end-toendmachine-learning-benefits-the-whole-supply-chain/ (Accessed 10 March 2020).

Стаття надійила до редакиї 17.03.2020 p.

www. economy.nayka.com.ua

Електронне фахове видання

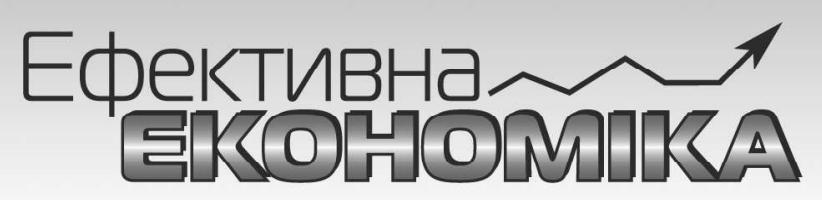

\section{Виходить 12 разів на рік}

Журнал включено до переліку наукових фахових видань України з ЕКОНОМІЧНИХ НАУК (Категорія «Б»)

Спеціальності - 051, 071, 072, 073, 075, 076, 292

e-mail: economy_2008@ukr.net

тел.: (044) 223-26-28

(044) $458-10-73$ 